\title{
Relações de gênero e acesso à educação: migrantes nordestinas no pontal mineiro (1950-1960)*
}

\author{
Daiane de Lima Soares Silveira** \\ Sauloéber Tarsio de Souza***
}

\section{Resumo}

Este artigo apresenta estudo sobre mulheres nordestinas que migraram com suas famílias para o Pontal Mineiro nas décadas de 1950 e 1960 e aquelas que nasceram nas referidas décadas. Pretende abordar a diferença de escolarização observada entre meninas e meninos, filhas e filhos de migrantes, que nasceram em Minas Gerais, repetindo a. situação verificada no espaço de origem - Rio Grande do Norte e Paraíba, estados de onde principalmente partiu o fluxo migratório -, em que as mulheres tinham superiores índices de alfabetização em comparação aos homens. Além disso, busca compreender as relações de poder entre homens e mulheres, analisando a formação cultural da figura do homem nordestino com o tipo conhecido de "cabra-macho", homem forte e violento que tem o domínio da casa e da família, e como, nesse quadro, a mulher soube aproveitar "brechas" e conquistar um espaço de emancipação por meio da educação escolar.

Palavras-chave: Migrantes nordestinas, Pontal Mineiro, Escolarização.

* Recebido em 04 de maio de 2015, aceito em 10 de outubro de 2018.

** Professora na Prefeitura Municipal de Ituiutaba, MG, Brasil. daianelss@hotmail.com / https://orcid.org/0000-0002-8607-4937 .

*** Professor e pesquisador no ICHPO/PPGED (UFU), Uberlândia, MG, Brasil. sauloeber@gmail.com / https://orcid.org/0000-0002-9797-341X. 
Gender Relations and Access to Education: Northeastern Migrants in Pontal Mineiro (1950-1960)

\begin{abstract}
This paper presents a study about women who migrated from Brazil's Northeast with their families to the "Pontal Mineiro" region in the 1950s and 1960s and of those who were born in these decades. It examines the difference in schooling between girls and boys born in Minas Gerais who are the children of migrants, which repeats the situation found in the states of Rio Grande do Norte and Paraíba, the main sources of migration, where women had higher literacy rates than men. A bibliographic review about women's education in those states is also presented. The paper also sought to understand the power relations between men and women, analyzing the cultural formation of northeastern man, particularly the type known as "billy-goat", a strong and violent man, who dominates the home and family and how women learn to find "gaps" and conquer a space of emancipation through schooling
\end{abstract}

Keywords: Northeastern Migrant Women, Pontal Mineiro, Schooling. 


\section{Introdução}

Eu ficava pensando assim:

Se eu não casar com ele, eu vou ficar trabalhando a vida inteira toda pros outros?

[...] Aí minhas primas falavam assim, as mais maior, as mais ativas falavam assim:

"ó, se você dormir com o cara, aí tem que casar na marra,

aí você sai da casa do seu pai, aí eles têm que deixar você casar".

Olha! Foi isso que eu fiz. Exatamente. (risos)

[...] Você aprende a amar. Gostar...

[...] Não tava com vontade.

Vou te falar a verdade, porque a gente não teve a oportunidade

assim de segurar na mão, beijar, namorar, você entendeu?

Você fazer um sexo já assim: namorou, conheceu e foi fazendo lentamente...

Eu era virgem. Aí depois que você chega numa certa idade, passado uns bons tempos,

é a mesma coisa de você tá dormindo e você tá sonhando

que você vai comer um queijo amanhã.

[...] Eu sonhava assim, alto.

Eu sonhava em casar, ter marido, ter casa, não trabalhar pros outros, mas tinha que aprender a gostar.

Então conforme o causo, não tinha muita escolha, aprender a gostar (Araújo, entrevista em julho de 2013).

Na epígrafe acima vemos um trecho da entrevista de Araujo, que nos conta qual a tática usou para que conseguisse esquivar-se de muitos sofrimentos $e$, de forma sincera $e$ poética, compara sua vida a um sonho. Essas táticas são relativas às possibilidades oferecidas pelas circunstâncias 
(Certeau, 1998). As migrantes nordestinas se mostraram fortes frente a muitos desafios quando chegaram, ainda crianças, no Pontal Mineiro. E um desses desafios foi garantir a sua escolarização, enfrentando o preconceito $e$ a situação social extremamente precária. Mais que isso, mostraram-se fortes quando, superando uma cultura de forte hierarquia masculina, destacaram-se alcançando melhor escolarização do que os homens. Em uma sociedade cuja "norma" foi e ainda é o masculino, elas se utilizaram de mecanismos e subterfúgios garantindo sua emancipação. "No 'padrão científico', o homem ou o masculino tem sido a 'norma' e isso se evidencia desde as elaborações linguísticas nas quais tradicionalmente se toma o masculino como sinônimo de humanidade" (Sayão, 2003:122).

A migração nordestina já é tema discutido pela historiografia nacional, quando trata de minorias, de excluídos, portanto de uma "memória subterrânea" (Pollak, 1989). Neste artigo referimo-nos à migração nordestina para o Pontal Mineiro, especificamente. Estudamos as migrantes nordestinas, as filhas que migraram com suas famílias ou mesmo as que nasceram na nova região, nas décadas de 1950 e 1960. A origem desse fluxo migratório é explicada pela divulgação em revistas e jornais, do processo de crescimento econômico da região de Ituiutaba ${ }^{1}$, em cujas terras férteis desenvolveu-se a cultura de cereais, principalmente o arroz $e$ em consequência a indústria de beneficiamento de grãos.

Como um dos objetivos desta pesquisa ${ }^{2}$, propusemonos a compreender a diferença de escolarização entre meninas e meninos migrantes e filhos e filhas de famílias migrantes, o que foi identificado anteriormente em um projeto de iniciação científica de que participamos na graduação. As

\footnotetext{
1 Ituiutaba era um dos polos econômicos da região do Pontal Mineiro.

2 Pesquisa de Mestrado em Educação na Linha de História e Historiografia da Educação (PPGED-UFU).
} 
meninas conseguiram maiores possibilidades de se escolarizar, enquanto os meninos tiveram mais dificuldades de se inserirem e permanecerem nas instituições escolares do município de Ituiutaba. Tal superioridade foi percebida a partir da dificuldade em localizarmos homens que se escolarizaram e, em contrapartida, nos depararmos com certa facilidade com mulheres migrantes que se inseriram e/ou permaneceram nas escolas ituiutabanas. Entendemos que os meninos, contribuindo com seus pais no sustento familiar, encontraram barreiras ao seu processo educacional. Embora as meninas, também colaborassem ativamente com a lida diária, puderam se escolarizar com significativa diferença deles.

Nossas análises se deram por meio de entrevistas ${ }^{3}$, dados do Instituto Brasileiro de Geografia e Estatística (IBGE) e fontes bibliográficas que versam sobre a educação da mulher no Rio Grande do Norte e na Paraíba, e que informam sobre a formação cultural do homem nordestino, a sua relação com o trabalho e sua escolarização.

Destaca-se que os indicadores educacionais do município de Ituiutaba e do estado de Minas Gerais apontavam, nos anos de 1950 e 1960, superioridade de alfabetização dos homens em relação às mulheres.

Nos estados do Rio Grande do Norte e da Paraíba, principalmente, onde se originou o fluxo migratório, verificamos que os índices do IBGE apontavam taxas mais elevadas de alfabetização para as mulheres relativamente aos homens, especialmente no primeiro estado. ${ }^{4}$ Tal realidade

3 No mestrado, entrevistamos onze mulheres e cinco homens, todos migrantes entre março de 2010 e julho de 2013, na cidade de ItuiutabaMG. Os nomes dos entrevistados são fictícios, atendendo às normas do comitê de ética da Universidade Federal de Uberlândia.

4 1950: Rio Grande do Norte (homens 26,78\% alfabetizados e mulheres $28,86 \%$ ); Paraíba (homens 26,06\%, mulheres 24,71\%); em Minas Gerais, $41,72 \%$ de homens alfabetizados, e $34,81 \%$ de mulheres; em Ituiutaba, 
permaneceu no Pontal Mineiro, quando da migração, pois como vimos, as migrantes nordestinas se escolarizaram mais do que os homens.

Frente a esses dados, esboçava-se importante problemática que procuraremos responder no decorrer deste artigo: em uma sociedade de hierarquia predominantemente masculina, haveria maior incentivo dos pais na escolarização das meninas em detrimento dos meninos? Mas, então, existiria uma intencionalidade protetora frente ao trabalho feminino? $\mathrm{O}$ investimento na escolarização das meninas teria o objetivo de reforçar inconscientemente o "[...] papel da mulher como reprodutora e guardiã da ordem, uma ordem que não se deve questionar com o trabalho feminino" (Dhoquois, 2003:45)?. Seriam então, essas meninas migrantes consideradas o "sexo frágil"? Foi realmente um incentivo ou as mulheres, aproveitando a ocasião, usaram certa astúcia?

Aproveita as ocasiões e delas depende, sem base para estocar benefícios, aumentar a propriedade e prever saídas. Este lugar não lhe permite sem dúvida mobilidade, mas numa docilidade aos azares do tempo, para captar no voo as possibilidades oferecidas por um instante. Tem que utilizar, vigilante, as falhas que as conjunturas particulares vão abrindo na vigilância do poder proprietário, Aí vai caçar. Cria ali surpresas. Consegue estar onde ninguém espera. É astúcia (Certeau, 1998:100).

Mesmo em face a um contexto social, econômico e cultural em que preponderava o domínio masculino, as mulheres migrantes nordestinas conseguiram manipular

45,81\% para os homens e 39,25\% para as mulheres. 1960: Rio Grande do Norte (Homens 35,70\% alfabetizados e Mulheres 40,82\%); Paraíba (Homens 32,51\% alfabetizados e Mulheres 33,77\%); Minas Gerais (53,15\% homens alfabetizados e $47,61 \%$ das mulheres). 
mecanismos e se sobressaírem na escolaridade. Todavia, algumas deram continuidade aos estudos somente depois de adultas, quando a luta pelos direitos da mulher estava em processo mais adiantado. Entendemos que esse empreendimento está relacionado a um processo que vem sendo construído a partir da luta feminina e feminista pela educação e emancipação da mulher.

Assim, apresentaremos breve discussão sobre a categoria gênero como possibilidade de análise das relações entre homens e mulheres, contribuindo para a compreensão do nosso objeto. Mostraremos a luta por emancipação e busca por direitos de educação no Rio Grande do Norte e na Paraîba. Por último, abordaremos a questão da formação da figura do homem nordestino e a relevância histórica do trabalho em relação à escolarização. Pretendemos mostrar que a valorização do trabalho, a formação cultural do "cabra macho", são questões que podem ter influenciado na diferença de escolarização das mulheres migrantes nordestinas em relação aos homens migrantes.

Gênero como categoria para os estudos das relações sociais e diferenças percebidas entre os sexos

A partir do final da década de 1980, os estudos sobre gênero começam a se destacar junto às ciências humanas. A historiografia também se volta a esse desafio colaborando com a investigação do gênero como um aspecto determinante das práticas sociais de homens e mulheres na sociedade. Mas Rago (1999) vem nos dizer que, desde a década de 1970, as mulheres se movimentaram de forma a inserir nas universidades seus próprios núcleos de estudos e pesquisas investigando novos temas que vão ao encontro de sua própria história. Há, portanto, significativa mudança na forma de se escrever a história das mulheres, no que diz respeito ao 
anterior silêncio e invisibilidade dos discursos e representações cotidianas e particulares da vida real.

De certo modo o passado já nos dizia e precisava ser re-interrogado a partir de novos olhares $e$ problematizações, através de outras categorias interpretativas, criadas fora da estrutura falocêntrica especular (Rago, 1999:84).

Rosemberg (2012) também traz considerações sobre o importante crescimento e a institucionalização dos estudos de gênero nas universidades e centros de pesquisas.

Nessas quatro últimas décadas vimos se expandirem os campos de estudos sobre educação e gênero, estudos feministas na educação - expansão associada, também, ao número crescente de mulheres educadas (estudantes, professoras e pesquisadoras na pósgraduação), seja na área específica de educação, seja nas diversas áreas do conhecimento (Rosemberg, 2102:349).

Nesse sentido, ao estudarmos o gênero numa perspectiva historiográfica, não podemos ficar alheios às relações sociais entre os sexos e os significados construídos nesses processos. Na pesquisa histórica, há que se pensar os discursos como forma de representação simbólica, conferindolhes significados, numa concepção de gênero como construção cultural.

Escrever sobre a história das mulheres, e particularmente sobre a história das relações sociais entre mulheres e homens no que se refere às representações relacionadas à instituição escolar, remete-nos a reflexões sobre os discursos aí produzidos. Todavia, nesta pesquisa nos deparamos com uma particularidade envolvendo as famílias e 
o contexto no qual elas estavam inseridas: as meninas tiveram melhor escolarização que os meninos.

Scott (1995) define a categoria gênero como um elemento constitutivo de relações sociais baseadas nas diferenças percebidas entre os sexos. Há maneiras de pensar essas diferenças muito engessadas e duais como ela mesma aponta: Eva e Maria como símbolos da mulher na tradição cristã ocidental, luz e escuridão, purificação e poluição, inocência e corrupção. Nesse mesmo sentido, Rosemberg conta que

no Brasil denegou-se a educação formal às mulheres em nome de sua "natureza corruptível": o modelo de educação feminina virtuosa até o século XIX era o de Sant'Anna Mestra, avó de Cristo, que ensinava a Virgem, sua filha, com seu livro de preces. Posteriormente, sustentou-se a necessidade de se educar as mulheres (comedidamente, porém) porque elas seriam "educadoras de homens", necessários à nação (Rosemberg, 2012:338).

Scott (1995) também explica que o gênero estaria imbricado às relações de poder, e sua análise seria uma forma primária de dar significado a essas relações. Portanto, nesta pesquisa buscamos compreender o que existe por trás da relação de poder entre pais e filhas migrantes nordestinas, pensando quais os significados que aparecem nessas interações. É nesse sentido que buscamos explicar a diferença de escolarização entre as mulheres e os homens migrantes. Veremos mais à frente que a figura do pai na família nordestina é culturalmente central, ou seja, é o topo da hierarquia. É sempre ele quem decide tudo e toma todas as decisões. Além do mais, a figura masculina é carregada de significados como de homem forte, violento e macho, cujo trabalho é seu maior esteio, ficando a escolarização em segundo plano. Por isso, Scott nos aconselha que, 
Devemos nos perguntar mais seguidamente como as coisas se passaram para descobrir porque elas se passaram; [...] Para buscar o significado, precisamos lidar com o sujeito individual, bem como com a organização social, e articular a natureza de suas interrelações, pois ambos são cruciais para entender como o gênero funciona (Scott, 1995:86).

Frente a essas circunstâncias, as mulheres migrantes, mesmo com outras tantas dificuldades como o preconceito $e$ os problemas sociais, souberam perceber brechas e garantir sua educação nas escolas tijucanas. Nesse sentido, Matos (1988) afirma ser

importante observar as diferenças sexuais enquanto construções culturais, linguísticas e históricas, que incluem relações de poder não localizadas exclusivamente num ponto fixo - o masculino -, mas presente na trama histórica. Bem como, investigar os discursos $e$ as práticas que garantem o consentimento feminino às representações dominantes e naturalizadas da diferença, o que não excluiria que à incorporação da dominação às variações, manipulações, táticas, recusas e rejeições por parte das mulheres, complexificando as relações de dominação históricas (Matos, 1998:70).

\section{A educação da mulher no Rio Grande do Norte e na Paraíba}

A partir de estudos realizados sobre a luta feminina que se deu principalmente nos jornais e revistas buscando emancipar e educar as mulheres no Rio Grande do Norte e na Paraíba, desde o final do século XIX, procuramos evidenciar aqueles espaços no processo educacional feminino. Destacamos alguns trabalhos que foram realizados sobre mulheres que se destacaram na busca pelo avanço da 
educação feminina. Importante dizer que tais mulheres faziam parte de reduzida elite de letradas, como jornalistas, escritoras e educadoras.

O Rio Grande do Norte foi um dos estados pioneiros na educação feminina. Temos como primeiro e importante exemplo, Nísia Floresta Brasileira Augusta (1818-1885), filha desse estado e precursora na defesa do saber para as mulheres. Nísia compartilhava de um discurso que defendia as "virtudes naturais" da mulher; acreditava que a elas estava reservada a responsabilidade pelas atitudes moralizadoras diante da família e pensava que a educação moral deveria ser o modelo maior de consciência dos seus deveres. Todavia, ela defendia que para tirar as mulheres da submissão, somente recorrendo à educação. Mais que isso, a educação proporcionaria às mulheres as condições imprescindíveis para serem donas de seus destinos (Duarte, 2010).

Vimos a história de Maria Dolores Bezerra Cavalcanti, contada por Melo e Morais (2002), que no início do século XX, como mulher literata e educadora, defendia a educação e a instrução femininas como uma forma imprescindível para que as mulheres saíssem do espaço privado conquistando uma parcela do espaço público. Juntamente com Isaura Carrilho, dirigiu um jornal manuscrito intitulado A Esperança (19031909), que tinha como objetivo divulgar publicamente a produção literária feminina local.

Carvalho (2004), em sua dissertação de mestrado, narra a história de Palmyra Wanderley, relacionando a vida da escritora e jornalista com a educação da mulher no Rio Grande do Norte do início do século XX (1914-1920). Palmyra produziu, editou e fez circular a revista literária Via-Láctea (1914-1915), em Natal.

A revista literária era uma publicação mensal, comprometida com a educação e interesse da mulher. Em outubro de 1914, nascia o primeiro veículo 
impresso feminino em terras potiguares, configurando uma publicação inovadora, uma vez que muitos periódicos eram manuscritos (Carvalho, 2004:78).

Como exemplo de artigos publicados por ela, tem-se: na quinta edição da revista, o texto intitulado $A$ emancipação da mulher e, no sexto número, o artigo $A$ educação da mulher. Palmyra Wanderley também fez parte da Aliança Feminina, formada por uma sociedade de senhoras da capital, que tinha, além de outras, a responsabilidade pelo Curso Comercial Feminino que funcionava na própria sede da Aliança.

Ainda temos a tese de doutorado de Machado (2001), Práticas de Escrita de mulheres do Seridó Paraibano (19601980), citada por Carvalho (2004), em que:

o autor discute a presença da religiosidade na produção escrita de mulheres educadoras e escritoras no cotidiano das suas relações sociais na região do Seridó Paraibano. Neste trabalho, o pesquisador propõe evidenciar a experiência na produção escrita naquela região, ligada às práticas culturais e religiosas dos sujeitos femininos. A prática da escrita feminina, dentro e fora da Igreja, representou uma transformação substancial na história da vida religiosa de algumas mulheres, pautada na utopia de se construir uma sociedade verdadeiramente fraterna (Carvalho, 2004:31).

Com o estudo do Atheneu Norte-Riograndense Feminino, vamos conhecer, também no início do século XX, uma importante conquista das mulheres daquele estado, através da luta por direitos iguais no que tange à educação. Lima e Morais (2008) narram a história da abertura desse colégio como "um espaço comprometido com a educação da mulher potiguar. Ele floresce com os primeiros anos do século 
XX, em 1903, acontecimento que demonstra as mudanças educacionais no Rio Grande do Norte" (Lima; Morais, 2008:s/p).

O colégio em sua gênese (1834) era voltado apenas para formação de rapazes da sociedade potiguar, mas com a demanda crescente de mulheres que ali requeriam um espaço, em janeiro de 1903, ocorre a aprovação das primeiras mulheres nos Exames Parcelares. "Essa conquista é um elemento peculiar na história das instituições, pelo fato de ter sido o Atheneu uma instituição que abriu suas portas para o público feminino graças à iniciativa das mesmas" (Lima; Morais, 2008:s/p).

Avançando um pouco mais no século XX, vamos conhecer o Jornal das Moças (1926-1932), por meio da dissertação de Rocha Neto (2002). Dando a conhecer a trajetória de suas produtoras, Georgina Pires, Dolores Diniz e Júlia Augusta de Medeiros, o autor faz uma análise da participação feminina na imprensa norte-rio-grandense na década de 1920. "Esse grupo de mulheres se propunha escrever sobre literatura, humorismo e críticas com relação à condição da mulher na sociedade norte-rio-grandense" (Rocha Neto, 2002:10).

Também na Paraíba, com a Página Feminina, da Associação Paraibana pelo Progresso Feminino (APPF) no jornal $A$ União - PB, analisada por Nunes (2008), verificamos mais um importante veículo de divulgação da luta das mulheres pelos seus direitos.

Embora preocupadas com as homenagens e com as justificativas de que a Associação não traria nenhum desajuste à sociedade paraibana, as mulheres procuravam, em seus textos, sempre deixar claro a importância e a necessidade de ser oferecida educação para a mulher, a fim de transformá-la em elemento impulsionador do progresso (Nunes, 2008:s/p). 
Vieira (2005), estudando as contribuições de Lia Campos na organização educacional do Rio Grande do Norte nos anos de 1950 e 1960, apresenta em sua dissertação os problemas de alfabetização vivenciados no estado, e mostra as ações dessa educadora no sentido de transformar a educação norte-riograndense. Foi a pedido do então Governador Dinarte de Medeiros Mariz que Anísio Teixeira, presidente do INEP à época, enviou a professora Lia Campos ao Rio Grande do Norte, em 1957. Até então a educadora morava e trabalhava no estado do Rio Grande do Sul, onde nasceu e se formou.

Convidada inicialmente para ministrar um primeiro curso de aperfeiçoamento para professores leigos, Lia Campos passou um mês na capital norte-riograndense; retornou alguns meses depois e assumiu a direção do Centro de Estudos Pesquisas Educacionais (CEPE), onde atuou por sete anos (1957-1964).

Podemos observar, assim, uma mulher à frente de um dos mais importantes órgãos do estado, que cuidava da educação no Rio Grande do Norte, o que vem ao encontro das percepções acerca da escolarização feminina de lá.

Essa bibliografia ${ }^{5}$ traz a história de mulheres que tiveram importante papel não apenas na educação, mas na literatura $e$ no jornalismo. Assim compreendemos que se formou, nesses estados, uma dada concepção, pois essas mulheres muito contribuíram para divulgar a importância da educação feminina como forma de emancipação.

Todavia, é necessário dizer que

nem sempre a defesa do acesso e progressão das mulheres à educação formal foi sustentada por razões

5 Ver ainda: Literatura Feminina no Rio Grande do Norte de Nísia Floresta a Zilá Mamede, de Duarte e Macedo (2001); e Educação de Mulheres em Assú - Rio Grande do Norte (1925-1955), de Silva, Morais e Silva (2008). 
emancipatórias para além da função domésticomaternal. Durante os séculos XIX e XX, e mesmo nesse início do terceiro milênio, tem sido possível encontrar a justificativa de que se deve investir na educação da mulher porque "mulheres educadas são melhores mães" (Rosemberg, 2012:338).

\section{A relação trabalho e educação para o homem e a mulher nordestinos}

Para compreender a diferença da educação escolar entre homens e mulheres migrantes nordestinos no Pontal Mineiro, é preciso compreender, também, as relações de poder envolvidas nesse processo. Para tanto, falaremos da construção da figura masculina do nordestino com todos os tipos conhecidos de "cabra macho", homem forte e violento, patriarca rural que tem o domínio da casa e da família, compreendendo que foram construídos e estimulados em determinado momento - início do século XX. Albuquerque Jr. contribui para que se conheça a respeito do homem nordestino com o livro Nordestino: invenção do "falo". Uma história do gênero masculino.

Assim, recuperando ainda a pergunta: se as meninas eram mais escolarizadas em relação aos meninos, de certa forma foram incentivadas ou conseguiram esse caminho como forma de encontrar uma saída, por que a escola? Entenderemos que essa concepção do masculino contribuiu para que determinada educação - a dos bacharéis - fosse considerada refinada, feminizada. Naquele momento, o pensamento corrente era de que os filhos da elite, que buscavam uma educação além da recebida no campo, tornavam-se delicados, menos homens.

Mais que isso, iremos observar que o trabalho tem relevante significação para o homem, principalmente $\mathrm{O}$ homem do campo. O trabalho tem primazia à escolarização para esse homem que acredita ser mais valorizado o esforço 
provedor, que garante o domínio de si e da família. Essa discussão far-se-á, também, a partir das contribuições apresentadas nos resultados de pesquisa realizada por Albuquerque Jr. (2012) em instituição de saúde denominada BEMFAM, nas cidades de Natal-RN e Recife-PE, na qual foram entrevistados 120 homens.

Albuquerque Jr. (2013) mostra a construção de um tipo regional de nordestino, no início do século $\mathrm{XX}$, mais precisamente entre os anos dez e os anos vinte através de imagens do cangaceiro, do coronel, do jagunço - figuras típicas do meio rural: "na historiografia e sociologia regional, na literatura popular e erudita, na música, no teatro, nas declarações públicas de suas autoridades, o nordestino é produzido como uma figura de atributos masculinos" (Albuquerque Jr., 2003:18). Há, portanto, uma imposição de "ser macho"; há a criação da ideia, do discurso de Nordeste e nordestino em que tipos vão sendo construídos.

A própria história da região traria as marcas de fortaleza, valentia e coragem ao homem nordestino, que teria que sobreviver às intempéries de uma natureza hostil. Os intelectuais que construíram tais discursos estavam ligados às elites e vão buscar no homem das camadas populares, principalmente do campo e do sertão, um modelo típico de masculinidade para ser generalizado para todo ser regional. As elites, consideradas "decadentes, moles e impotentes, as novas elites burguesas, homens delicados e de punhos de renda" (Albuquerque Jr., 2003:56), que não conviviam com as duras e rústicas experiências do campo, não serviriam de modelo a esse tipo regional que se pretendia construir, a fim de contrariar a nova cultura, dita moderna, que ameaçava as tradições da região.

São os filhos e genros dos velhos patriarcas que, bacharéis na administração pública ou empresários, vão nivelar $e$ até inverter a hierarquia entre jovens e velhos. 
Bacharéis que, em sua estadia na cidade, ao atingirem a adolescência, não foram mais iniciados pelas carnes negras e mestiças das escravas ou mulheres pobres do campo, mas pelas cocotes estrangeiras, mulheres de carne branca $e$ de modos refinados, que teriam contribuído para refinarem estes homens, fazendo deles quase umas moças.[...] $\mathrm{O}$ bacharelismo era mais uma forma de desvirilização. Homem que era homem, na sociedade do tempo dos patriarcas rurais, não gostava de livros, apreciava era "uma boa pinga, um bom cavalo, uma boa briga de galo e uma boa mulata" (Albuquerque Jr., 2003:56).

Por meio da educação, a forma de ser nordestino teria sido transmitida pelas famílias a seus filhos, garantindo a autoridade absoluta do pai, pessoa em torno da qual giravam seu poder, suas vontades e suas expectativas. O pai deveria ser respeitado para ser visto como homem de verdade, não devendo "voltar para casa afrontado". A masculinidade exacerbada era estimulada desde cedo, pois quando o menino estava chorando ouvia que aquilo não era coisa de homem, que era vergonha chorar em público, como se estivesse fazendo algo errado (Albuquerque Jr., 2013).

Podemos observar, então, todo um discurso construído e mantido em torno do nordestino "cabra-macho" e rústico. Além disso, percebemos que o trabalho deveria ser uma das marcas desse homem masculinizado, cujo corpo descuidado, estaria fortemente afeito ao trabalho.

Um dos entrevistados fala da dificuldade em estudar, pois necessitava do trabalho para colaborar com o pai na lida da fazenda: "Estudava a metade do ano, seis meses, três meses, parava tudo de volta, ia trabalhar" (Pacheco, 2010).

Ademais, de acordo com esse discurso, a necessidade de prover a própria vida - o trabalho seria o meio - levaria a certa depreciação da escola por ser um espaço que pode 
privar os homens do domínio de si mesmos e de se garantir provedores (Albuquerque Jr., 2012).

Apareceu de uma forma clara entre os entrevistados uma contradição entre um discurso de valorização da educação, mas acompanhado do reconhecimento da pouca disposição para frequentar a escola. Os meninos parecem não se adequar ao regime disciplinar exigido pela escola e rejeitam ficar horas imobilizados numa sala de aula, parecendo valorizar aventuras $e$ atividades que lhes possam desde cedo dar o domínio sobre si e acesso a meios de proverem a própria vida: "Eu nunca me interessei (...) comecei tocar violão na Igreja muito cedo, com nove anos já estava tocando. Aos onze anos eu saí para tocar fora, com profissionais" (Albuquerque Jr., 2012:s/p).

Como vimos, nas experiências dos migrantes nordestinos não foi diferente o discurso nas relações de gênero e nas formas educativas. Uma das entrevistadas nesta pesquisa fala da experiência dos seus pais quanto à educação, dizendo que somente a mãe havia frequentado escola, diferente do pai.

Meu pai... Minha mãe estudou um pouco em Mossoró, quando ela morava com a família em Mossoró. Ela fez tipo assim, segunda série. Meu pai nunca foi pra escola, mas ele aprendeu a ler e a escrever com o Assilino, um amigo dele. Assilino tinha um professor e ele trabalhava pro pai do Assilino. Aí o Assilino... O professor ensinava na escola... Porque naquela época não tinha escola, era os professor que ia nas casas. Aí o professor ensinava o Assilino e Assilino pro meu pai. Escrevia na areia do rio. Não existia lápis, nem caneta, né. Aí escrevia, ele pegou e aprendeu. Ele lê e escreve pouca coisa que ele aprendeu foi nas areia, porque no Nordeste as areia é branquinha! E eles ficavam 
escrevendo. E ele aprendeu. Foi! (Ribeiro, entrevista realizada em 2010).

\section{O trabalho e a escolarização dos migrantes nordestinos no Pontal Mineiro}

Pudemos notar que o trabalho era, desde cedo e em grande medida, parte integrante da vida daquele que chegava ao Pontal Mineiro, ficando a escolarização em segundo plano. O entrevistado Pacheco corrobora com essa afirmação ao dizer que, apesar de haver escola, a família havia mudado não para estudar, mas para trabalhar. "Desde que nós chegamos já fomos pra escola. Mas estudava dois dia, três dia e... dois, três dia e ia trabalhar, porque aqui viemos foi pra trabalhar, não foi pra estudar".

No entanto, essa era uma condição dos meninos, porque quando perguntado se conhecia algum colega migrante que deu sequência aos estudos, Gouveia assim respondeu:

Desses, ó, eu conheço, não eu num lembro bem não. Eu sei que eles, até quando nós vivemos juntos assim, quando era rapaz, solteiro, deve ter ficado só com aquilo mesmo, né?! A não ser alguma mulher. Acho que alguma prima da gente conseguiu, né?! Mas os homens, né, ficaram complicado mesmo (Gouveia, entrevista realizada em 2013).

Há ainda o caso do Freitas que teve oportunidade de estudar na cidade a convite de parentes, mas segundo ele, preferiu o trabalho na fazenda. "Eu não tive paciência de ficar dentro de escola". Em sua fala, podemos observar, além disso, a questão da autoridade paterna:

Porque minha mãe não apitava nada, era uma coitadinha. Agora o meu pai falou: "não quer ir vai ficar na roça, vai trabalhar, vai puxar enxada". Porque 
o serviço de roça é bravo. Se a gente trabalha, é capinar, é quebrar milho, é plantar feijão na mão, sabe; bater feijão com os cambito marrado um no outro, sabe (entrevista realizada em 2013).

Esse migrante nordestino aparece na figura 1 junto a trabalhadores em uma lavoura. Na imagem, há apenas homens (adultos e crianças), mas como veremos mais à frente as mulheres também colaboravam nos trabalhos da roça. Isso demonstra que o trabalhador nordestino, especialmente o do campo, para garantir o poder na hierarquia familiar, relacionava o trabalho à figura masculina. Além disso, podemos observar que as crianças menores estão abaixo na foto, também, numa representação de hierarquia.

\section{Figura 1 - Trabalhadores na Lavoura}

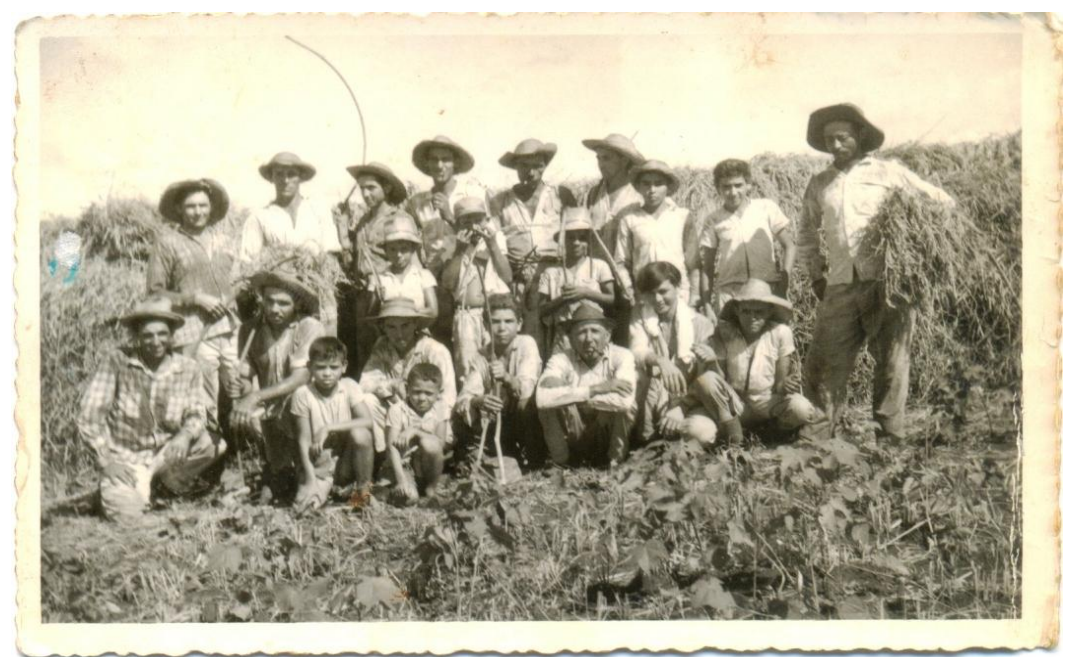

Fonte: Acervo particular Freitas. 


\section{Figura 2 - "Março de 1967 uma lembrança dos meus amigos na} colheta [colheita]"

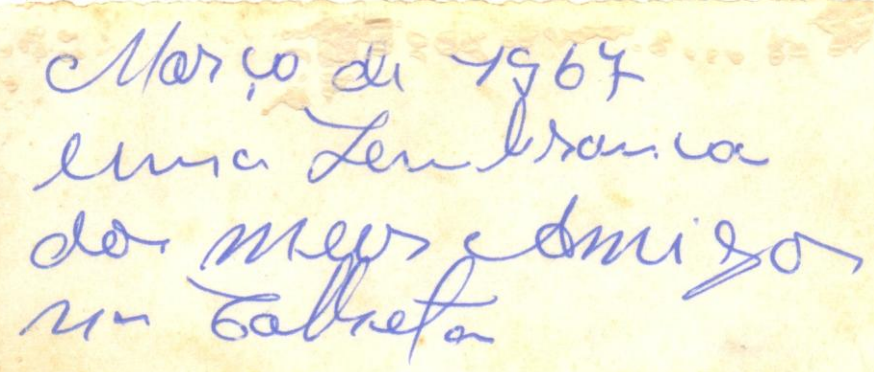

Fonte: Acervo particular Freitas.

Para melhor compreendermos a importância do trabalho para o homem nordestino $e$ as hierarquias nele presentes, apoiamo-nos nas contribuições trazidas por Heredia (1979), autora que estuda a organização interna das familias camponesas que fazem parte de uma forma de campesinato $^{6}$ marginal à plantation ${ }^{7}$ açucareira da Zona da Mata de Pernambuco.

${ }^{6}$ Segundo Heredia (1979:17): "Unidade de produção e unidade de consumo, visto que os membros que a compõem estão relacionados a priori ao processo produtivo e mediante laços de parentesco".

7 O professor Moacir Palmeira estuda a plantation e as mudanças por ela sofrida, no que diz respeito a sua estrutura interna. Seu estudo iniciou em 1969 abarcando as referidas mudanças que ocorreram em épocas próximas a essa data. Foi através desse estudo que Heredia tomou conhecimento da existência de um campesinato que teve formação em torno da mesma época, na área, e cujo surgimento estava ligado às transformações ocorridas na própria plantation (Heredia, 1979). 
Na pesquisa da referida autora evidenciou-se uma clara divisão das tarefas por sexo e idade. Da oposição masculinofeminino surge outra oposição que realmente dá sentido à divisão de tarefas: casa-roçado ${ }^{8}$, sendo que há uma hierarquia que define efetivamente o que é trabalho e o que não é trabalho. À mulher estão destinadas todas as atividades relacionadas com a casa. A ela é conferida a responsabilidade por cuidar e executar junto às crianças todas as tarefas que envolvem aquele espaço. Porém, é em torno da figura paterna que giram todas as decisões do roçado: o controle das tarefas; a decisão do tipo de cultivos e a disposição e combinação deles até o momento em que os produtos serão colhidos. Todavia, as mulheres atuam em várias fases do cultivo no roçado, mas o seu trabalho não é considerado como tal.

Embora os filhos desenvolvam no roçado as mesmas tarefas que o pai, diz-se que os filhos ajudam o pai de família, indicando-se assim que eles estão sob sua autoridade, [...] as mulheres desenvolvem tarefas no roçado; [...] a semeadura é uma atividade considerada feminina e é realizada exclusivamente por mulheres. Além disso, cabem a elas outros tipos de tarefas, como por exemplo, as limpezas periódicas que os cultivos requerem depois de serem plantados, embora homens e crianças também participem desta atividade. [...] Considera-se assim que a mulher não trabalha, e este princípio é mantido mesmo quando ela, em certas ocasiões, realiza tarefas no roçado (Heredia, 1979:80).

A entrevistada Leal conta que a mãe a levava para a roça, e narra o trabalho que realizava.

8 Fazia parte do roçado as culturas de mandioca, milho, feijão, cará, abacaxi, pimentão, alface, jerimum, tomate, repolho, cenoura, cebola, melancia, melão e outros, sendo que os três primeiros eram os que de fato tinham importância no roçado. 
Com oito anos de idade eu já trabalhava. Minha mãe levava nós pra roça, pra nós catá, é... arroz, milho. O que desse na lavoura que tava perdendo no chão, nós catava. Catava de sol a sol. De sete da manhã, no sábado, né, porque na semana nós ia depois do almoço. Das sete da manhã às sete da noite. Colocava um chapéu na cabeça. Nós! Catava mesmo! Sabe! Era bom, divertido! Depois aquele dinheiro que, ela vendia aquela mercadoria, milho, arroz, aí ela vinha pra cá, fazer compra, nós ganhava de tudo: calçado... o que nós precisava, né. Era uma vida boa! Eu lembro assim... (Leal, entrevista em abril de 2013).

Em seguida, quando perguntamos se ela trabalhava com os pais ela faz questão de afirmar: "É trabalhava com meu pai".

Essa predominância da figura paterna é percebida nas entrevistas que realizamos com os filhos dos migrantes nordestinos. Quando perguntado como era a sua casa na infância, Pacheco respondeu enfatizando o domínio do pai: "Muito bem repartida, era a casa do meu pai. Então eu lembro disso tudo direitinho. Na casa do meu pai morava o meu pai mais a minha mãe e nós irmãos, somente". Depois quando perguntamos sobre a convivência, a imagem do pai ainda se faz dominante, tanto que não menciona a mãe:

Muito boa, muito boa. Do meu pai com nós, com todo mundo, com os filhos, o meu pai com os parente dele, os irmão, os filho, o sogro, o pai dele. Toda a comunidade inteira era um sonho só, um povo maravilhoso, ainda é até hoje (Pacheco, entrevista em abril de 2013).

Encontramos um discurso recorrente em algumas entrevistas que também demonstra o domínio paterno. "Eu lembro meu avô... Se nós tivesse conversando aqui e passasse 
um moleque aqui, ai ai. Voltava pra trás ou ele tinha o dele" (Costa, entrevista em 2013). E Leal também afirma:

Não podia fazer nada errado. Tinha que andar certo. Se por acaso tivesse duas pessoas conversando igual eu e você está conversando. Se uma de nós, ou eu ou minha irmã passasse no meio, o veio dava só uma olhada assim ó. Nega vuava dali, né. Não podia! Não podia! (entrevista em 2013)

Quanto ao trabalho relacionado ao controle do pai, também pudemos verificar nos relatos dos entrevistados que sempre destacam a imagem paterna, como no da migrante Ribeiro:

Meu pai, toda vida foi muito trabalhador, a gente sempre fala isso. Nós toda vida comemos, feijão, arroz e carne. Nós toda vida tinha pra comer, né. Feijão, arroz, carne e ovos. A gente nunca passou fome. Porque os outros fala, né, que passou fome, que sofreu isso, aquilo tudo. Nós não. Era essas dificuldades. Mas nós não andava descalço, porque nós tinha nossos chinelos, né. E nós não andava descalço, nós tinha roupa e ainda tinha mais um... E quando nós tinha... Quando eu tinha tipo dez anos, aí pronto, aí o papai já era todo pra frente, já tinha, nós já andava... Mas toda vida trabalhando, todo vida nós trabalhava. Dia $e$ noite, na lavoura (Ribeiro, entrevista em abril de 2010).

Cintra é outro entrevistado que também revela, em suas próprias palavras, o domínio do pai sobre os filhos mediante o trabalho na roça:

Como diz, o papai criou a gente trabalhando, sabe. Ele ia pra roça, como ele teve lavoura aqui com o $\mathrm{Sr}$ Lavínio de Faria, teve lavoura, é..., com vários 
fazendeiros, e ele levava os filhos pra trabalhar. Os filhos maiores. Quer dizer, isso facilitou um pouco, assim, o domínio dele sobre os filhos, né?! (Cintra, entrevista em fevereiro de 2011).

A vida cotidiana vivenciada no Nordeste era, em muitos aspectos, reproduzida no Pontal Mineiro - rituais religiosos, festas, a reunião de pessoas, entre outros. Todavia, a questão da idade apresentada por Heredia (1979) como algo da cotidianidade das famílias campesinas difere do que foi narrado pelos entrevistados. A maioria dos entrevistados aponta que a partir de 7 ou 8 anos já realizavam atividade ligadas à lavoura, enquanto que a pesquisadora da Zona da Mata pernambucana verificou uma idade mais tardia, iniciando-se aos 10 anos. $^{9}$

Toda vida eu tive vontade de trabalhar, toda vida eu trabalhei, desde os sete anos. Mais assim, a gente ia trabalhar... me machucava. Mais aquilo, não existia remédio. Que que fazia? Eu ia trabalhar no meio do meu pai. Fazia assim tipo um mutirão pra limpar, essas coisas assim... então aquilo chamava de mão, as pessoas davam de mão. Naquela época era assim: as pessoas vinham davam de mão na casa do outro $e$ assim ia. E eu ficava no meio, só que eu cortava os pé. E pra ninguém ver, para eu não sair do meio deles lá, eu jogava terra por cima. Agora você imagina! E eles não viam [...] já pensou como que era as coisas? (Gouveia, entrevista em abril de 2013)

No trecho a seguir, veremos o relato de uma entrevistada que começou a trabalhar com 7 anos, pois como percebemos as mulheres também colaboravam na lida diária,

9 Uma possível explicação para essa diferença é que a posição de migrante $e$ as condições sociais mais precárias levaram à necessidade da colaboração dos filhos ainda mais novos no trabalho da família. 
mas ao que parece, aqui também, o seu trabalho não tinha o mesmo valor que o trabalho masculino. Porém, as mulheres souberam aproveitar o que seria um aviltamento, em prol de si mesmas, indo em busca de sua escolarização.

Quando eu comecei a trabalhar, eu tinha sete anos. O meu primeiro emprego era pegar cavalo no pasto. De quatro e meia da manhã. Por que que eu pegava os cavalo no pasto? Porque os cavalo... A gente chamava: os cavalo ficou veiaco. [...] Os homem ir com um prato de sal eles não queria, porque sabia que ia trabalhar na lavoura. Era! [...] E as criança... eu era menina, mas como eu era muito ativa, era eu e meu irmão. Toda vida eu quis muito bem meu irmão. Meu irmão quase da minha idade e tinha medo, coitadinho. Então nós dois era bom de pegar os cavalo. Aí nós levantava de quatro e meia da manhã e entrava no pasto. Naquela época chovia muito e tinha muito orvalho. Aí nós entrava no pasto, capim batia aqui (mostrou na altura do peito). Saía molhadim! [...] Aos sete anos eu puxava cavalo, puxar cavalo é... Os homem iam carpiderar e tinha que ter uma pessoa, porque tinha uns cavalos que era bravo. Aí a gente ia segurando nas rédeas do cavalo pra cima e pra baixo na lavoura, o dia inteiro, com chapéu e tudo. Tomava muita mordida de cavalo na cabeça. Mordida! (Ribeiro, entrevista em abril de 2010).

Ainda outro relato em que a narradora conta que colaborava, juntamente com a mãe, nos trabalhos pesados da roça:

Porque meu pai trabalhava, mexia com uma vendinha pra tirar o ganha pão pra gente e minha mãe ajudava na roça. É, plantava mandioca, plantava batata doce, plantava milho. Aí o que acontecia? Como nós era tudo pequeno, nós somos cinco irmão, nós tinha que 
ajudar. Eu mesma que era a mais velhinha. Todo mundo capinava na enxada, na enxada mesmo! No sol quente. A gente tinha que capinar, trabalhar. $\mathrm{O}$ meu pai mexia com arroz, a gente tinha que carregar aqueles pacotão de arroz pra ajudar bater também o arroz, né?! E o meu pai punha peão. Então a gente trabalhava como se fosse assim umas boiada, aquele tantão de gente - o meu pai com a gente, a minha família, né?! (Araújo, entrevista em 2013).

Pudemos compreender, então, que semelhante ao que se passava com as famílias da Zona da Mata pernambucana, estudadas por Heredia (1979), as famílias migrantes nordestinas tinham como centro hierárquico a figura do pai, e o trabalho masculino como mais importante do que o trabalho feminino, de tal forma que este último nem era considerado trabalho. Essa depreciação fortaleceu as migrantes que, superando barreiras, pois também eram ativas na lida diária, conseguiram se escolarizar mais que os meninos.

Além disso, havia uma imposição dos pais, e mesmo dos patrões, para que os meninos colaborassem mais efetivamente no trabalho na lavoura.

$\mathrm{Na}$ narrativa de Pacheco, a seguir, vemos que os meninos precisavam trabalhar, devendo afastar-se dos estudos:

Escola foi pouco, certo. [...] O pai não dava conta, chegou aqui, certo. E aquilo você vai crescendo, aí você vira rapazinho e não dá conta de estudar, que é preciso... aí eles precisa do seu serviço mesmo. Os próprio patrão não aceita você estudar muito, porque eles precisa do seu serviço. Se ocê for pra escola durante o ano, como é que faz? Aí não tem serviço. Aí você não estuda. [...] Eu estudei um tempo. Aí parava e ia trabalhar (Pacheco, entrevista em 2010). 
Em outros trechos pudemos confirmar tal realidade: "Tem um pessoal que chama... Uns nortistas, que veio com nós que chama familia Bailão, nunca foi na escola. Só uma das moças ou duas, que ia com nós, lá no Capinópolis" (Pacheco). Outra entrevistada afirma:

eu tiro pelo cunhado meu. A minha irmã teve muito filho, eles morava na fazenda... Difícil! "Pobre de Jó". Então tinha muito menino homem. Não queria que os filho estudasse, queria só que trabalhasse (Franco, entrevista em 2010).

Embora o trabalho, conforme entendemos, tenha importância central na vida do homem nordestino, a ponto de a educação escolar ficar em segundo plano, ouvimos falas de alguns migrantes, cujas reflexões demonstraram certa decepção por não terem continuado os estudos. São as "aspirações frustradas" de que nos fala Thomson (1997), marcando as lembranças muitas vezes dolorosas do passado. Quando perguntado se sentia falta da escola, pois na maior parte do tempo tinha que trabalhar, Pacheco assim responde:

Sentia falta e muita falta! Nossa... Eu tinha vontade ir pra escola. Às vezes eu já ia trabalhar e outros ainda ia pra escola, porque os pais tavam com mais condições. $\mathrm{E}$ os filhos daqueles de lá não tavam tão sendo obrigado a fazer... Aí eu saía da escola pra trabalhar e os outro ainda ia. E eu chorava de vontade ir com os outros, mas não podia ir, né?! Não tinha como eu ir. "Não meu filho você não pode, agora nós têm que trabalhar, nós têm que colher o arroz, colher o milho; nós têm que zelar disso aqui, se não nós também não come. Se ocê for estudar, faz falta aqui." Então era assim. Aquele jogo de empurra, um pouquinho pra cada lado. Mas funcionava (Pacheco, entrevista em 2010). 
Gonçalves estava falando do incentivo que deu aos seus filhos para que estudassem e, então, falou dele mesmo: 'Eu queria ter formado sim, mas não consegui"! (Gonçalves, entrevista em 2013).

O trabalho que começava tão cedo era uma imposição do pai, cujo processo de formação cultural - homem como provedor - fazia-se perceber como necessidade, agravada pela situação social difícil de migrante.

Quanto às meninas, como vimos, iniciavam na colaboração cotidiana, também muito novas, mas sem representar o mesmo valor que se dava aos homens. De qualquer forma, suas narrativas mostraram vidas repletas de luta, nas quais elas mesmas procuraram se valorizar.

Encontramos depoimentos de muita luta para que essas mulheres conseguissem a sua emancipação por meio da educação e do trabalho. A migrante Borges (2013), por exemplo, fez curso de costura e tentou retornar aos estudos depois de casada, dando continuidade ao segundo ciclo do fundamental, mas havia conseguido uma tão almejada vaga em um tão esperado emprego.

Então aí, mas tem luta, eu fui trabalhar, cheguei aqui fui lavar roupa pros outro, [...] eu fiz curso de costura com a filha de um fazendeiro. Eu falei: "eu quero fazer porque quando eu chegar lá na cidade eu sei fazer alguma coisa". [...] aí quando eu fiz 36 anos, os meninos já tava grande, aí eu falei, eu vou procurar alguma coisa pra mim, pro meu futuro, pra minha aposentadoria, vou entrar no Estado. $E$ ia daqui, ia dali, ia daqui, ia dali, e num arrumava vaga. Aí, um dia, a Maria Inês que trabalha na prefeitura, [...] aí eu falei com ela, ela falou "nossa o dia que eu ficar sabendo que tem vaga" - ela era inspetora das escola - "eu te aviso". Ah, um dia ela me ligou na minha vizinha e falou "Borges, vai ter, vai ter chamada na escola". [...] Aí eu trabalhei lá um ano. Cheguei aqui 
"consegui arrumar um serviço pra mim", feliz da vida. Aí meu marido falou "mas num vai de jeito nenhum, que é longe demais e eu num vou buscar". E eu falei, "num vou o quê? Vou", e fui, fui, até que ele aceitou, sabe? Porque, aí fui, aí fiquei lá um ano, aí no outro ano teve chamada novamente, eu fui pro João Pinheiro, fiquei lá no João Pinheiro dez ano, trabalhando à noite (Borges, entrevista em 2013).

Essa migrante narrou um interessante episódio de luta em sua vida, quando o estado de Minas Gerais promoveu um concurso e ela e outras 10 mulheres foram aprovadas, mas as colegas mais antigas, aquelas que já estavam idosas não conseguiram efetivar-se no cargo, adiando por muito tempo a aposentadoria. Borges envolveu-se bastante na luta por essas mulheres, organizando viagens até Belo Horizonte para exigir, junto aos políticos, o direito de aposentadoria para as prejudicadas. "Eles me consideram eu como uma líder, sabe?" (Borges, entrevista em 2013).

Algumas dessas migrantes estão trabalhando até hoje, como a Pereira que ainda recebe roupas das freguesas para lavar na própria casa. Outras, já aposentadas, ajudam os filhos a cuidar dos netos.

Quando perguntamos à Pereira com quantos anos $e$ onde começou a trabalhar, ela respondeu que foi com 12, 13 e elogiou muito a sua primeira patroa. Fez questão de mostrar uma foto (Figura 3) em que estão presentes: ela, a Patroa, a mãe e o irmão da entrevistada.

Foi na casa da Clarisse que é esposa do Florival. [...] Ela comprou as coisinha pra mim, enxovalzinho, sabe? Com o pai dos meninos aí, dos meus meninos que eu tenho. (risos) Foi, ela me ajudou muito. Dava roupa, dava de tudo, além do dinheirinho que eu ganhava. Ela me deu tudo. Também minha filha, lavo, passo... você baba! Isso aí pelo menos uma virtude que Deus 
me deu, porque ah... uma virtude que Deus me deu... lavar e passar. Era meu emprego aqui na cidade. Até hoje eu larguei de mão, porque eu não posso sair pra trabalhar na casa de ninguém por causa da menina. Então, mas elas sempre estão trazendo. É uma roupa de festa. É uns pano pra clarear. É... muita coisa assim que eles, às vezes, põem pra alguém fazer, que alguém não faz. "Eu trago, porque você sabe fazer. Não precisa nem eu falar que jeito que eu quero, que eu sei que você arruma direitinho, do jeito que eu gosto". Então eu aprendi isso aí com ela, com a minha patroa da fazenda (Pereira, entrevista em 2013).

Essa mulher não é mais casada e teve que cuidar dos três filhos, praticamente sozinha, desde quando eles ainda eram pequenos. A sua filha (menina), que ela cita na entrevista, tem sérios problemas de saúde, requisitando a presença constante da mãe. Assim, embora sua fala pareça sem conscientização no que se refere à relação empregadopatrão, podemos entender que, no mínimo, a partir do aprendizado que teve na fazenda onde trabalhava, ela conquistou certa autonomia podendo trabalhar em casa, provendo a si e a sua família, o que não deixa de ser uma emancipação. 


\section{Figura 3 - Casa da Patroa}

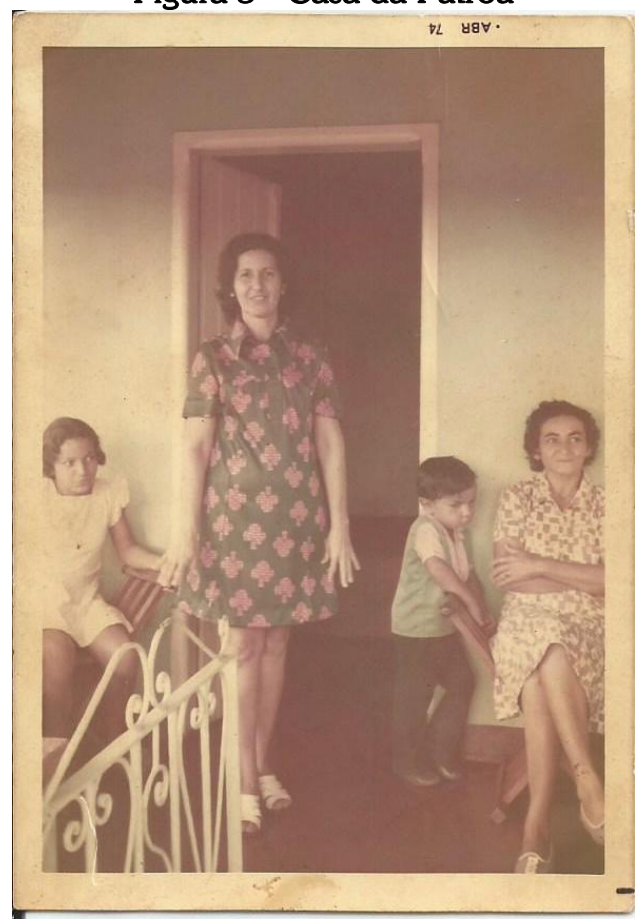

Fonte: Acervo particular Pereira.

Rosemberg (2012) questiona as interpretações quanto ao progresso das mulheres na educação que se inspiram em discursos arcaicos e que naturalizam diferenças sexuais ou literalmente discriminam as mulheres, como as que colocam causas exteriores à escola. A socialização familiar, que geraria maior docilidade das meninas e empurraria a participação mais intensa e precoce de rapazes no mercado de trabalho, seria uma dessas interpretações. Compreendemos que no caso das migrantes, há uma relação com o trabalho, no sentido de que a família dava mais valor ao trabalho masculino. Porém, diferentemente de trazer "docilidade" às mulheres, elas se mostraram mais fortes e garantiram sua 
inserção nas instituições escolares e muitas vezes concluíram a graduação.

\section{Considerações finais}

A diferença de escolarização das migrantes nordestinas em relação aos migrantes nordestinos faz parte de um complexo processo, que nos parece envolver a concepção acerca do que é ser homem e a visão sobre a educação de homens e mulheres, na região Nordeste.

Embora tenhamos mostrado números positivos no tocante à escolarização feminina, é importante revelar que

o acesso mais intenso das mulheres à educação escolar não tem garantido de fato uma igualdade de oportunidade a toda e qualquer mulher, bem como a experiência da coeducação; isto é, meninos e meninas, rapazes e moças não vivenciam o mesmo currículo, pois a antiga segregação sexual escolar, com seus currículos diferenciados, deixou suas marcas. Tem-se observado, e denunciado desde os anos 1970, uma segregação sexual informal que ocorre mesmo nas escolas mistas: quando a escola permite, isto é, abre perspectivas de diferenciação, meninos e rapazes tendem a seguir, preferencialmente, trajetórias escolares com conteúdos tecnológicos e das Ciências Exatas; meninas e moças se voltam para Ciências Humanas, Letras e Literatura, Magistério. Quando, no Brasil, esta especialização por sexo podia ocorrer, a partir do antigo ginásio já se observavam crianças, desde os 11 anos de idade, a fazer tais "escolhas", que se mantinham constantes no ensino médio e no ensino superior (Rosemberg, 2012:352).

Sabemos que a diferença sexual biológica acarreta marcas culturais e que, historicamente, suscitam desigualdades e hierarquias que não se modificam facilmente. 
Acreditamos que o que se passou com as mulheres nordestinas, tanto como migrantes, quanto em seus estados de origem, foi uma especificidade, cujas "falhas" elas souberam aproveitar manipulando determinada situação. Dessa forma, pensamos que há muito ainda o que transformar para que realmente haja mais igualdade de gênero e a "norma" ou "padrão" deixe de ser o homem ou o masculino.

\section{Referências bibliográficas}

AlbuQUeRQue Jr., Durval Muniz de. Nordestino: invenção do "falo": Uma história do Gênero Masculino (1920-1940). São Paulo, Intermeios, 2013, pp.13-254.

AlBuquerque Jr., Durval Muniz de. Mulher de casa pra gente é da rua pro outro": masculinidades e práticas sexuais em cidades do nordeste

[http://www.cchla.ufrn.br/ppgh/docentes/durval/artigos/mulher_d e_casa_pra_gente_e_da_rua_pro_outro.pdf - acesso em 18 abr. 2012].

CARVAlHo, Isabel Cristine Machado de. Palmyra Wanderley e a Educação da Mulher no Cenário Norte-Rio-Grandense (1914 1920). Dissertação (Mestrado em Educação), Universidade Federal do Rio Grande do Norte, Natal, 2004.

Certeau, Michel de. A invenção do cotidiano: Artes de fazer. Petrópolis-RJ, Editora Vozes, 1998, pp.9-351. Tradução de Ephaim Ferreira Alves.

DHOQUOI, Régine. O direito do trabalho e o corpo da mulher. (França: séculos XIX e XX). Proteção da produtora ou da reprodutora? In: MATOS, Maria Izilda S. de; SOIHET, Raquel. (org.). O corpo feminino em debate. São Paulo, Ed. da UNESP, 2003, pp.43-56.

DuARTE, Constância Lima. Nísia Floresta. Recife, Fundação Joaquim Nabuco, Editora Massangana, 2010. 
HerediA, Beatriz Maria Alásia de. A Morada da Vida: Trabalho familiar de pequenos produtores do Nordeste do Brasil. Rio de Janeiro, Paz e Terra, 1979, pp.15-164.

LIMA, Elisangela Gurgel Rocha; MoRAIS, Maria Arisnete Câmara. O Atheneu Norte-Riograndense Feminino, sua História. In: $V$ Congresso Brasileiro de História da Educação, de 9 a 12 de novembro de 2008, Aracaju, SE [http://www.sbhe.org.br/novo/congressos/cbhe5/pdf/783.pdf acesso em 17 jul. 2019].

MATOS, Maria Izilda. S. de. Estudos de Gênero: percursos e possibilidades na historiografia contemporânea. cadernos pagu (11), Campinas-SP, Núcleo de Estudos de GêneroPagu/Unicamp, 1998, pp.67-75.

MElO, Elisângela de Araújo Nogueira; MORAIS, Maria Arisnete Câmara de. Contribuição Feminina à História da Educação no Rio Grande do Norte: Maria Dolores Bezerra Cavalcanti. II Congresso Brasileiro de História da Educação. Natal, RN, de 3 a 6 de novembro de 2002 [http://sbhe.org.br/novo/congressos/cbhe2/pdfs/Tema5/0504.pdf - acesso em: 17 jul. 2019].

NunES, Maria Lúcia da Silva. Uma Página Feminina: Vozes de Mulheres Paraibanas na Década de 1930. V Congresso Brasileiro de História da Educação, de 9 a 12 de novembro de 2008, Aracaju-SE

[http://www.sbhe.org.br/novo/congressos/cbhe5/pdf/580.pdf acesso em: 17 jul. 2019].

POLlaK, Michael. Memória, esquecimento, silêncio. Estudos Históricos vol. 2, $\quad \mathrm{n}^{\circ} \quad 3, \quad 1989 \quad$ pp.3-15 [http://www.uel.br/cch/cdph/arqtxt/Memoria esquecimento silenc io.pdf - acesso em: 17 jul. 2019].

RAGO, Margareth. A "nova" historiografia brasileira. Anos 90, n¹1, Porto Alegre, jul. 1999, pp.73-96.

RochA Neto, Manoel Pereira. O Jornal das Moças (1926-1932): Educadoras em Manchete. Dissertação (Mestrado em Educação), Universidade Federal do Rio Grande do Norte, Natal, 2012. 
ROSEMBERG, Fúlvia. Educação: Mulheres Educadas e a Educação de Mulheres. In: PINSKY, Carla Bassanezi; PEDRO. Joana Maria. (org.). Nova História das Mulheres no Brasil. São Paulo, Contexto, 2012, pp.333-359.

SAYÃO, Deborah Tomé. Corpo, poder e dominação: um diálogo com Michelle Perrot e Pierre Bourdieu. Revista Perspectiva vol.21, n 01, Florianópolis, jan./jun.2003, pp.121-149.

ScotT, J. W. Gênero, uma categoria útil de análise histórica. Educação \& Realidade vol. 20, n 2, Porto Alegre, jul./dez. 1995, pp.71-99.

Thomson, A. Recompondo A Memória: Questões sobre a relação entre a História Oral e as memórias. Projeto História, n ${ }^{\circ} 15$, São Paulo, abril 1997, pp.51-71.

VIEIRA, Daniel Fonseca. As mudanças da educação do RN nos idos de 1950 e 1960: a prática de Lia Campos. Dissertação (Mestrado em Educação), Universidade Federal do Rio Grande do Norte, Natal? OK, 2005.

\section{Entrevistas:}

GOUVEIA, C. [abril, 2013].

PEREIRA, M. A. [junho, 2013].

PACHECO, L. B. [abril, 2013].

LEAL, M. A. [abril, 2013].

RIBEIRO, L. N. [abril, 2010].

GONÇALVES, F. G. [julho, 2013].

BORGES, M. F. [abril, 2013].

CINTRA, P. F. [fevereiro, 2011].

ARAúJO, L. S. [julho, 2013].

FRANCO, A. O. [março, 2010 e abril, 2013]. 